\title{
Effects of Pesticide Toxicity on Animal Health and Ecosystems; The Importance of Using Safe Pesticides.
}

\section{Özge Temiz*}

Department of Biology, Faculty of Science and Arts, Çukurova University, Adana,

Turkey

*Corresponding Author: Özge Temiz, Department of Biology, Faculty of Science and Arts, Çukurova University, Adana, Turkey.

DOI: $10.31080 /$ ASVS.2020.02.0043
Received: December 27, 2019

Published: February 01, 2020

(c) All rights are reserved by Özge Temiz., et al.
Pesticides are heterogeneous and large amounts of chemical groups used to control and remove pests. Pesticides used in pest control have always been a source of concern for human life [1,2]. Pesticides used in different fields, pesticides are used in order to eliminate agricultural pests to produce agricultural products and to obtain a clean food source, and to control infectious diseases such as malaria and a significant amount of pesticides [3,4]. Human are exposed to pesticides in various ways. Food production of plant and animal origin, and through this production air and water contaminated pesticides reach ecologically. The circulation and accumulation of pesticides in the food chain leads to the formation of high amounts of pesticide residues. Since pesticides are formed as toxic chemicals for living organisms, their toxicity to human, nontarget organisms and the environment can be determined by oxidative stress mechanisms [5-8]. Pesticides have greatly benefited human life by increasing the yields of agricultural products. The wide variety of pesticides leads to intensive use. Therefore, both pesticide applications and accumulation in the food chain constitute human health occupational and environmental risks. Exposure to pesticides can cause permanent health problems for human health. nerve, endocrine, immune, reproductive, renal, cardiovascular and respiratory systems and human health. Thus, exposure of the pesticide has been found to be linked to the development of human chronic diseases such as parkinson, alzheimer, cancer types, multiple sclerosis (MS), diabetes, aging, cardiovascular and kidney disease [9-11]. Living systems encounter various stresses during their continuous interactions with their environment such as feeding and breathing. Stress is induced as a result of metabolicinduced chemical processes induced by metabolic activities that occur as a necessity of life. It activates the production of endogenous reactive oxygen species (ROS) produced as by-products of respiration in living organisms [12]. The formation of ROS provides an equilibrium by providing biotransformation in living organisms with antioxidant system mechanism. Oxidative stress occurs with overproduction of ROS and insufficient antioxidant system. Oxidative/antioxidative imbalance results in damage to macromolecules such as DNA, protein and lipids. Thus, constant exposure to stressors such as pesticides can cause oxidative stress and antioxidant system mechanisms are maintained against cellular ROS, and the increase in damage of macromolecules with oxidative damage can be minimized by repair systems [13]. The most active varieties of the ROS family are in the biochemical process; superoxide radicals $\left(\mathrm{O}_{2}-\right)$, hydroxyl radicals $(\mathrm{OH})$ and hydrogen peroxides $\left(\mathrm{H}_{2} \mathrm{O}_{2}\right)$ cause damage to the functional structures of lipid, protein and nucleic acid structures in the cell. Antioxidant system as the first step enzymes CAT (catalase) and SOD (superoxide dismutase) are considered. With the formation of superoxide radicals, SOD enzyme is converted to $\mathrm{H}_{2} \mathrm{O}_{2}$ by biotransformation and $\mathrm{H}_{2} \mathrm{O}_{2}$ is detoxified by CAT in the cell [14]. Peroxidation of lipids disturbs the integrity of cell membranes and leads to rearrangement of membrane structure. Glutathione peroxidase (GPX) is a protective antioxidant that acts along with catalase (CAT) in scavaging out hydrogen peroxide to ensure optimum protection against oxidative stress and tissue specific damage. Glutathione reductase (GR) catalyzes the reduction of glutathione disulfide (GSSG) to the sulfhydryl form glutathione (GSH), which is a critical molecule in resisting oxidative stress and maintaining the reducing environment of the cell [4].

Evaluation of oxidative stress induction in organisms exposed to pesticides are important parameters for determination of toxic effects of pesticides. That pesticides can reach the ecosystem; Further studies are needed to clarify the oxidative mechanisms of their impact on aquatic life, water quality and human health. Given the health and environmental toxic effects, the use of pesticides should be limited with a new plan in agriculture. This new plan can be replaced without compromising the reasons for the effective use of pesticide applications and may result in health, environmental and economic benefits $[15,16]$. In pesticide applications it is important 
not to exceed the legally determined safe levels. Consequently, the "safe level" impacts on the environment and human health are important [17].

\section{Bibliography}

1. Williams AL., et al. "Developmental and reproductive outcomes in humans and animals after glyphosate exposure: critical analysis". Journal of Toxicology and Environmental Health, Part B: Critical Reviews 15.1 (2012): 39-96.

2. Temiz 0., et al. "Influence of chlorantraniliprole toxicity on ionic regulation of gill and muscle ATPase activity of nile fish (Oreochromis niloticus)". Fresenius Environmental Bulletin 27 (2018): 5027-5032.

3. Sanborn M., et al. "Non-cancer health effects of pesticides. Systematic review and implications for family doctors". Canadian Family Physician 53 (2007): 1712-1720.

4. Astiz M., et al. "The impact of simultaneous intoxication with agrochemicals on the antioxidant defense system in rat". Pesticide Biochemistry and Physiology 94 (2009): 93-99.

5. Hemingway J and Ranson H. "Insecticide resistance in insect vectors of human disease”. Annu Rev Entomol 45 (2000): 371391.

6. Goulson D."Ecology: pesticides linked to bird declines”. Nature 511 (2014): 295-296.

7. Eisenstein M. "Pesticides: Seeking answers amid a toxic debate". Nature 521 (2015): 52-55.

8. Temiz 0. "Effects of fungicide propiconazole on oxidative stress parameters and antioxidant system enzymes in liver of Oreochromis niloticus". Journal of Anatolian Environmental and Animal Sciences 4.1 (2019): 43-47.

9. De Souza., A., et al. " Evaluation of the impact of exposure to pesticides on the health of the rural population: Vale do Taquari, State of Rio Grande do Sul (Brazil)". Ciência and Saúde coletiva 16.8 (2011): 3519-3528.

10. Mostafalou S and Abdollahi M. "Concerns of environmental persistence of pesticides and human chronic diseases". Clinical and Experimental Pharmacology 2.3 (2012): 1000-1108.

11. Mostafalou S and Abdollahi M. "Pesticides: an update of human exposure and toxicity". Archives of toxicology 91.2 (2017): 549-599.
12. Sharma Y., et al. "Dimethoate-induced effects on antioxidant status of liver and brain of rats following sub chronic exposure". Toxicology 215 (2005) 173-181.

13. Üner N., et al. "Piperonyl butoxide increases oxidative toxicity of fenthion in the brain of Oreochromis niloticus". Journal of Biochemical and Molecular Toxicology 28.2 (2014): 84-90.

14. Damien C., et al. "Cellular impact of metal trace elements in terricolous lichen Diploschistes muscorum (Scop.)R. Sant. -identification of oxidative stress biomarkers". Water Air and Soil Pollution 152 (2004): 55-69.

15. Temiz $\mathrm{O}$ and Kargin F. "Determination of toxic effects of biopesticide emamectin benzoate in the tissues of Oreochromis niloticus by acetylcholinesterase enzyme activity". Journal of Anatolian Environmental and Animal Sciences 4.1 (2019): 3438.

16. Papadakis EN., et al. "A pesticide monitoring survey in rivers and lakes of northern Greece and its human and ecotoxicological risk assessment". Ecotoxicology and Environmental Safety 116 (2015): 1-9.

17. U.S. Environmental Protection Agency (USEPA). "ECOTOX User Guide: ECOTOXicology Database System”. Version 4.0. (2015).

\section{Assets from publication with us}

- Prompt Acknowledgement after receiving the article

- Thorough Double blinded peer review

- Rapid Publication

- Issue of Publication Certificate

- High visibility of your Published work

Website: www.actascientific.com/

Submit Article: www.actascientific.com/submission.php Email us: editor@actascientific.com

Contact us: +919182824667 